\author{
Bartłomiej Krawczyk \\ Uniwersytet Jagielloński \\ bkrawczyk151@gmail.com
}

\title{
Hans Joas - koncepcje wojny i przemocy
}

\section{Hans Joas: Ideas of War and Violence}

\begin{abstract}
The author presents the ideas of war, violence and peace as formulated by the German sociologist Hans Joas. He shows Joas's point of view on ideas of how to maintain a long-term peace which appeared since the $18^{\text {th }}$ century, and presents the scholar's proposal concerning the close analysis of the mythology of violence. The article also describes Joas's theory of the emergence of values in the context of violence, the origins of human rights and the use of the narrative as a way of overcoming trauma.
\end{abstract}

Keywords: war, sociology, Hans Joas, violence, peace, human rights, Alfred Döblin, trauma

Streszczenie: Autor przedstawia koncepcje wojny, przemocy i pokoju niemieckiego socjologa Hansa Joasa. Ukazuje punkt widzenia Joasa na pojawiające się od XVIII wieku koncepcje utrzymania długotrwałego pokoju oraz przedstawia propozycję badacza dotyczącą uważnej analizy mitologii przemocy. Przedmiotem opisu jest także teoria Joasa dotycząca powstawania wartości na gruncie przemocy, pochodzenia praw człowieka oraz użycia opowieści jako sposobu na wyjście z traumy.

Słowa kluczowe: wojna, socjologia, Hans Joas, przemoc, pokój, prawa człowieka, Alfred Döblin, trauma

Czym są wojny, jaka jest ich geneza i znaczenie społeczne, jakie mechanizmy do nich prowadzą? Czym jest pokój i jak sprawić, by trwał jak najdłużej? Odpowiedzi na te pytania tylko pozornie są proste, w gruncie rzeczy wymagają zaś poważnego namysłu. Dotychczasowe koncepcje, sięgające często XVI wieku, zostały zdezaktualizowane przez kolejne procesy społeczne oraz wydarzenia historyczne - rozpad feudalizmu i monarchii absolutnych, industrializację, zagrożenie zagładą ludzkości w wyniku użycia broni atomowej, a ostatnio terroryzm. Obie wojny światowe (szczególnie druga, z masową eksterminacją ludności cywilnej i reżimami totalitarnymi) były wielkimi wstrząsami dla biorących w nich udział społeczeństw. Stanowią też mocną cezurę dla samoświadomości współczesnej kultury (jak się zdaje nie tylko Zachodu) 
oraz wytworzyły polityczny ład, który istnieje do dzisiaj. Niestety, sytuacja międzynarodowa i polityczna - rozwój różnych form ekstremizmu, ataki terrorystyczne, walki na Ukrainie - zmusza do przyznania, że z trudem wypracowana stabilizacja jest zagrożona, a XXI wiek również może być stuleciem konfliktów. Namysł nad istotą wojny, pokoju i przemocy wydaje się więc nadal niezbędny. W rozważaniach dotyczących tych problemów wartościowe mogą być prace naukowe niemieckiego socjologa Hansa Joasa. Celem tego szkicu jest przedstawienie wyników jego badań, ukazanie nowych, socjologicznych interpretacji wojny i przemocy.

Hans Joas (urodzony w 1948 roku) wydaje się w Polsce mało znany ${ }^{1}$, warto zatem przywołać najważniejsze informacje dotyczące jego osoby. Joas jest socjologiem, aczkolwiek jego prace często wykraczają poza ramy tej dyscypliny ku historii, filozofii, politologii, literaturoznawstwu. Pole jego zainteresowań badawczych obejmuje problemy nowoczesności, religii, sekularyzacji, wojny, procesów działań twórczych, powstawania wartości. Polski czytelnik może znać go z jedynej przetłumaczonej na nasz język książki, gdzie przedstawia swoją koncepcję powstawania wartości jako wyniku samoformowania i samotranscendencji ${ }^{2}$ oraz rekonstruuje poglądy najważniejszych myślicieli (od Friedricha Nietzschego do Charlesa Taylora), którzy zajmowali się wspomnianym problemem. W książce tej widoczna jest także szczególna cecha wszystkich prac Joasa - głębokie ugruntowanie w historii idei oraz zderzanie różnych, historycznych analiz dotyczących danego problemu, tak by ujawniły się niezauważane dotąd sposoby interpretacji. Duże znaczenie ma też dla niego tradycja amerykańskiego pragmatyzmu, czego wyrazem były jedne z pierwszych jego książek: George Herbert Mead: A Contemporary Re-examination of His Thought oraz Pragmatism and Social Theory. Koncepcje Meada i Johna Deweya stanowiły także podstawę argumentacji Joasa w jego The Creativity of Action, gdzie przedstawił nową teorię twórczego charakteru ludzkich działań (w opozycji do istniejącego przekonania o ich racjonalnym czy normatywnym charakterze) - książka ta przyniosła autorowi duże uznanie, szczególnie w Stanach Zjednoczonych. Warto przy tym zaznaczyć, że Joas zajmuje się tematami, które w myśli socjologicznej były często pomijane, oraz nie stroni od krytyki dominujących teorii i dyskursów. Do najważniejszych jego książek

${ }^{1}$ W przeciwieństwie do Europy Zachodniej i Stanów Zjednoczonych, czego wyrazem są choćby prestiżowe wyróżnienia: Nagroda Hansa Kiliana, Nagroda Badawcza Maxa Plancka oraz ostatnio Nagroda Paula Ricoeura za rok 2017.

${ }^{2}$ H. Joas, Powstawanie wartości, tłum. M. Kaczmarczyk, Warszawa 2009, s. 10-11. Terminy Selbstbildung i Selbsttranszendenz, którymi w wielu swoich pracach posługuje się Joas, tłumaczę jako „samoformowanie” i „samotranscendencja”, inaczej niż zrobił to Michał Kaczmarczyk w swoim przekładzie Powstawania wartości, gdzie użył sformułowań „kształtowanie się jaźni” i „przekraczanie jaźni”. Uważam, że proponowane przeze mnie wersje są bliższe zamysłowi Joasa. Tłumacz na język angielski, Gregory Moore, wykorzystał określenia self-formation i self-transcendence. 
należą: The Creativity of Action, War and Modernity, Do We Need Religion? On the Experience of Self-Transcendence, The Sacredness of the Person: A New Genealogy of Human Rights, Faith as an Option: Possible Futures for Christianity. Jego ostatnie badania skupiają się na problemie „epoki osiowej” i jej znaczenia dla kształtu współczesności³.

W refleksji Joasa nad problemem wojny, pokoju i przemocy można wyodrębnić kilka bardziej szczegółowych zagadnień. Pierwsze z nich stanowi jego krytyka socjologii i nauk politycznych, które według badacza w niewystarczający sposób zajmują się kwestią konfliktów między państwami. Warto w związku z tym zająć się opisem najważniejszych koncepcji społecznych, które obiecywały długotrwały pokój, oraz rozważań Joasa poświęconych Realpolitik i mitologii przemocy. Na koniec zaś rozpatrzę jego własną teorię powstawania wartości na gruncie przemocy oraz badania dotyczące mechanizmu wychodzenia $\mathrm{z}$ wojennej traumy i budowania uniwersalistycznych praw po drugiej wojnie światowej.

\section{Krytyka socjologii i nauk politycznych}

Punktem wyjścia w badaniach nad istotą wojny jest dla Joasa zaskakujące w gruncie rzeczy stwierdzenie, że socjologia oraz nauki polityczne nie wypracowały dotąd rozbudowanej i usystematyzowanej teorii konfliktu zbrojnego ${ }^{4}$. $\mathrm{Z}$ jednej strony nauki polityczne mają małe znaczenie w rozwoju ogólnych teorii wojny, pokoju i przemocy, ponieważ paradygmat ich bliski jest liberalizmowi, który nie przykłada wielkiej wagi do problemu przemocy. W doktrynie liberalnej przemoc bowiem uważana jest za relikt przeszłości, społeczeństw tradycyjnych, skostniałych, zmilitaryzowanych. Nawet jeśli istnieje w społeczeństwach liberalnych, będzie z nich wypierana przez racjonalizm i procesy modernizacyjne ${ }^{5}$. Joas podważa zasadność tych stwierdzeń, a w procesie modernizacji widzi nie tylko szanse, ale także zagrożenia. $Z$ drugiej strony podobne przeoczenie problemu wojny zauważa też w dziedzinie socjologii. Jego

${ }^{3}$ Epoka osiowa (termin stworzony przez Karla Jaspersa) obejmuje środkowe wieki I tysiąclecia p.n.e., w których na obszarach Azji i Europy wytworzyły się sformalizowane modele myśli religijnej i filozoficznej. Badania nad epoką osiową mają na celu zrozumienie powstania pojęcia „ludzkości”, rozwoju uniwersalizmu moralnego oraz wytworzenia religijnych i mitycznych fundamentów świadomości współczesnego człowieka. W interdyscyplinarnych pracach oprócz Joasa biorą udział jedne z najważniejszych postaci współczesnej humanistyki i nauk społecznych, między innymi Charles Taylor, José Casanova, Robert N. Bellah. Por. The Axial Age and Its Consequences, red. R.N. Bellah, H. Joas, Cambridge-London 2012, s. 10-29.

${ }^{4}$ Warto jednak zauważyć, że sytuacja ulega znacznej poprawie. Dowodem na to są choćby badania Sinisa Maleševicia czy Martina Shawa. Zob. S. Malešević, The Sociology of War and Violence, Cambridge 2010; M. Shaw, War and Genocide: Organised Killing in Modern Society, Cambridge 2003.

${ }^{5}$ H. Joas, War and Modernity, tłum. R. Livingstone, Malden 2003, s. 29-31. 
zdaniem co najwyżej pojedynczy naukowcy, szczególnie z okresu pierwszej wojny światowej, zajmowali się tym tematem, ale ich koncepcje nie tworzą ścisłych teorii ${ }^{6}$. Fakt to zaskakujący, tym bardziej że Joas w swoich badaniach sięga do myślicieli z XVI wieku, którzy stworzyli podstawy nowoczesnego myślenia o wojnie. Pojawienie się tej problematyki wiązało się ze stabilizacją koncepcji państwa i umacnianiem się monarchii absolutnych, a swój najdobitniejszy wyraz znalazło w pismach Hugona Grotiusa i Thomasa Hobbesa ${ }^{7}$. Nie jest oczywiście problem wojny zagadnieniem zupełnie nowym i ma długotrwałe tradycje.

Odnosząc się do współczesnej socjologii, Joas przytacza dwa główne nurty interpretacji genezy przemocy. Pierwsza skupia się na socjostrukturalnej charakterystyce sprawców. Uznaje przemoc za działanie, które przekracza granice prawne i moralne, jest jednak podejmowane $\mathrm{z}$ racjonalnych pobudek. W szerszym kontekście jawi się więc ona jako pewna forma społecznego protestu, będącego udziałem szczególnie tych grup, które uznają się za pokrzywdzone, wykluczone, pozbawione nadziei na poprawę swojej pozycji. Joas zauważa przy tym, że socjolodzy posługujący się tą teorią, mimo że nie popierają samych aktów agresji, to są zazwyczaj skłonni usprawiedliwiać sprzeciw, który się za ich pośrednictwem ujawnia. Drugi nurt interpretacji uznaje przemoc za obecność lub brak pewnych wartości. W pierwszym wypadku za destabilizację wini się istnienie tradycyjnych, militarystycznych ideałów lub wyraźną obecność wojen w dziejach danego społeczeństwa. Pojawia się jednak, szczególnie w obecnych czasach, takie rozumienie konfliktów, które ich korzeni dopatruje się w upadku lub braku norm dotąd powstrzymujących społeczeństwo od przekraczania granic. Najczęściej przywołuje się zanik moralności i zmniejszenie znaczenia autorytetów ${ }^{8}$.

Joas zauważa, że wytłumaczenia te nie do końca są jednak satysfakcjonujące: nie wyjaśniają momentu pojawienia się przemocy, nie mogą ująć jej wewnętrznej dynamiki oraz nie opisują, w jaki sposób pojedyncze przypadki urastają do groźnych fal agresji. Dodajmy też, że interpretacje te nie tłumaczą jasno problemu genezy wojny. Pytanie podstawowe bowiem brzmi: w jaki sposób konflikty wewnątrz społeczeństwa przekładają się na politykę zagraniczną państwa?

Podsumowując sprawę nieobecności tematu wojny w teoretycznej, systematycznej myśli socjologicznej i politologicznej, warto wspomnieć, że zdaniem Joasa konflikt zbrojny przyciąga szczególne zainteresowanie społeczeństwa, ponieważ odznacza się „interpretacyjną intensywnością". Z Zódła tej intensywności są różne. Po pierwsze, wojna jest wydarzeniem nadzwyczajnym

\footnotetext{
6 Tamże, s. 18-27, 125-127.

7 H. Joas, W. Knöbl, War in Social Thought, tłum. A. Skinner, Princeton 2013, s. 16-19.

${ }^{8}$ H. Joas, War and Modernity, dz. cyt., s. 187-188.

9 Tamże, s. 3-4.
} 
dla społeczności. Po drugie, stanowi wyzwanie dla istniejących interpretacji, waloryzacji, tradycji - Joas na ten aspekt kładzie zresztą szczególny nacisk ${ }^{10}$. Konflikty zbrojne i sytuacje politycznego napięcia są „eksperymentami kryzysowymi" - wydarzeniami historycznymi empirycznie sprawdzającymi, naturalnie falsyfikującymi nie tylko dotychczasowe teorie, ale także i całe struktury społeczne ${ }^{11}$. Po trzecie wreszcie, wojna stymuluje powstawanie nowych wartości i odczytań. Brak przełożenia między tym społecznym zainteresowaniem wojną a badaniami naukowymi jest więc znamienny.

\section{Najważniejsze koncepcje dotyczące wojny, pokoju i przemocy}

Prace Joasa ujawniają zaskakujący fakt: akceptowane współcześnie interpretacje i teorie dotyczące wojen - ich genezy, znaczenia, sposobu uwolnienia się od nich - nie wychodzą z osobnych teorii przemocy między państwami, a raczej z holistycznych systemów rozumienia świata, czy szerzej rzecz ujmując ideologii, dla których problem konfliktu zbrojnego ma niewielkie znaczenie. Historia myślenia o długotrwałym pokoju sięga już średniowiecznego Pax Romana, skoncentrowanego wszakże tylko na krajach chrześcijańskich, a pierwsze typowo uniwersalistyczne projekty przyniosły dopiero renesans i reformacja. Jednak to epoka oświecenia wygenerowała dojrzałe próby spojrzenia na ten problem. Od tego czasu pojawiło się co najmniej pięć wielkich idei politycznych, które, mimo że często marginalnie dotykały problemu utrzymania stabilnego, długotrwałego pokoju, w znacznym stopniu kształtowały myślenie na temat możliwości uniknięcia wojen. Są to: ekspansja wolnego handlu, ustanowienie republik, rozwój społeczeństwa przemysłowego, socjalizm, istnienie silnych przymierzy nuklearnych ${ }^{12}$.

Doktryna rozwoju wolnego handlu (którą Joas określa jako utylitarną wersję myślenia o długotrwałym pokoju) od XIX wieku w głęboki sposób rzutowała nie tylko na politykę i społeczeństwo, ale także na poglądy na temat wojny. Wymiana dóbr ma większe znaczenie niż konflikt zbrojny - i dla jednostki, i dla rozwoju społeczeństw, dlatego według Adama Smitha jako jedyna może zapewnić trwały pokój. Konflikt zbrojny jest nieekonomiczny i trzeba go rozumieć jako egoistyczne działania niektórych grup i władców, nie zaś wyraz pragnień całego społeczeństwa. Joas zauważa jednak, że koncepcja utylitarystyczna sama rodziła kolejne niebezpieczeństwa i spory. W znaczny sposób faworyzowała ona bowiem państwa handlowe i potęgi morskie, sprzyjała

\footnotetext{
10 Tamże, s. 17-18.

11 Tamże, s. 128, 136-137.

12 Tamże, s. 127-129.
} 
agresywnej kolonizacji, a w ogólnym kontekście stanowiła fundament tak zwanego imperializmu wolnego handlu ${ }^{13}$.

Od ryzyka tworzenia sytuacji konfliktowych nie jest wolna również koncepcja republikańska. Jeden z głównych jej przedstawicieli, Immanuel Kant, w odpowiedniej równowadze między prawami, władzą a obywatelami widział sposób na powstrzymywanie wojen. Republikanizm dąży do uniwersalizacji określonych zasad i norm - co jest też niejako jego pułapką. Jak wykazał Carl Schmitt, doktryna ta bardzo szybko każdy konflikt zbrojny zaczyna przedstawiać nie jako spór dwóch państw, ale jako walkę sił dobra ze złem. Prowadzi to do eskalacji konfliktów i zamienienia ich w swego rodzaju bezwzględne krucjaty, w których liczy się tylko ostateczne zniszczenie przeciwnika.

Joas zauważa, że obie te doktryny, republikańska i utylitarystyczna, stały się tak ważne i dominujące ze względu na ich umocowanie w rzeczywistości oraz że rzadko występowały osobno, najczęściej łączyły się w swego rodzaju syntezie. Na ich gruncie powstały też dwie inne idee polityczne, które miały olbrzymie znaczenie dla historii XIX i XX wieku. Jedną jest marksizm, inną rozwój społeczeństwa przemysłowego.

Marksizm podkreśla rolę walki, ale tylko w fazie kreowania społeczeństwa socjalistycznego - po zdobyciu go i utrwaleniu zniknąć ma kapitalizm, który jest podstawowym źródłem konfliktów w nowoczesnym świecie. To, co miałoby nastać później, to rzeczywistość pozbawiona przemocy i wojen. Jednak, jak zauważa Joas, wszelkie próby ustanowienia porządku marksistowskiego prowadziły dotąd jedynie do większego przelewu krwi.

Postacią istotną dla powstania kolejnej idei był Herbert Spencer. Stworzył on rozróżnienie na dwa typy społeczeństw. Militarne, w ramach którego wola jednostki jest ograniczana w imię siły grupy, opiera się na kolektywnej zdolności do stosowania przemocy skierowanej na zewnątrz swoich granic. Drugie to propagowane przez Spencera społeczeństwo przemysłowe, nastawione pokojowo, w którym jednostki mają możliwość samorozwoju, wszystko ulega decentralizacji, a potencjał grupy polega na sile jednostek. Ewolucjonistyczna nadzieja Spencera na to, że zbiorowości wojownicze naturalnie wyginą, na razie jednak się nie sprawdza.

Po drugiej wojnie światowej na gruzach czterech wizji długotrwałego zapobiegania konfliktom: republikańskiej, wolnego handlu, społeczeństwa industrialnego i marksizmu, pojawiła się koncepcja pokoju gwarantowanego przez przymierza i potęgę atomową. Ceną takiego ładu był podział świata na dwa obozy, między którymi często dochodziło do niebezpiecznych tarć (jak choćby kryzys na Kubie) oraz zagrożenie zagładą całej planety w wyniku wojny nuklearnej. Od lat osiemdziesiątych odczuwano jednak kruchość wytworzonej stabilizacji. Joas uważa, że dziesięciolecie to było kolejnym „eksperymentem

${ }^{13}$ Opis tej i kolejnych koncepcji długotrwałego pokoju: tamże, s. 127-137. Krytyczne uwagi o koncepcji republikańskiej i wolnego handlu: tamże, s. 34-38. 
kryzysowym", który ujawnił ukrywane dotąd mechanizmy i przekonania społeczeństw. Przyczyną załamania się istniejącego ładu były rozwój nowych technologii wojskowych, a także klęski ekologiczne (jak awaria reaktora atomowego w Czarnobylu). Kwestie te nasilały tendencje do wspólnych, globalnych działań naruszających istniejącą równowagę sił. Podział świata na dwa obozy i groźba użycia broni atomowej zdolnej zniszczyć całą ludzkość nie były więc wystarczającym, bezpiecznym i długotrwałym rozwiązaniem.

Przeciwko nadziejom na ponadczasowy, uniwersalny ład, których odzwierciedlenie Joas znajduje w pięciu wyżej wymienionych koncepcjach, od początku występowali tak zwani archaiczni militaryści, uważający, że wojna jest ojcem wszystkich społeczeństw, a pokojowa, antywojenna cywilizacja prowadzi do moralnego upadku. Powoływali się oni na wnioski wyciągnięte z prac Charlesa Darwina i innych badaczy, które racjonalnie uzasadniały rywalizację między jednostkami, narodami, grupami etnicznymi. Reprezentantami takiego stylu myślenia byli między innymi pierwsi socjolodzy: Ludwik Gumplowicz i Gustav Ratzenhofer. Inna antypacyfistyczna grupa to staroświeccy militaryści, którzy swoje przekonania wiązali z filozofią życia lub egzystencjalizmem. Przemoc rozumieli jako akt twórczy i doświadczenie fundamentalne. Braterstwo żołnierzy frontowych miało stanowić zalążek nowych relacji społecznych. Ten styl myślenia szczególnie silnie występował w okresie pierwszej i drugiej wojny światowej. Obecnie obie te grupy nie mają już takiego znaczenia jak choćby sto lat temu ${ }^{14}$. Inaczej wygląda to w wypadku trzeciej grupy antypacyfistów: wyznawców idei Realpolitik, którzy w polityce widzą niezmiennie tylko konflikt interesów, a w działaniach poszczególnych państw jedynie dbałość o własne powodzenie ${ }^{15}$.

W tej sytuacji według Joasa występuje dylemat: oświecenie, liberalizm i marksizm, które w znacznej mierze wytworzyły pięć koncepcji długotrwałego pokoju, dają nadzieję na życie bez wojny, lecz wciąż wystawiają nas na przemoc (a nawet, jak marksizm, wskazują na jej - co prawda krótkotrwałą - konieczność). Militaryzm, darwinizm społeczny oraz Realpolitik kierują zaś naszą uwagę na rolę konfliktów, odzierają jednak z każdej nadziei na stabilizację. Joas uważa, że wyjście z tego impasu polega między innymi na dekonstrukcji Realpolitik oraz właściwym rozpoznaniu istniejących mitologii przemocy. Pozwoli to uniknąć ograniczeń, które występowały w tworzonych dotychczas koncepcjach pokoju.

Realpolitik, zdaniem Joasa, tylko pozornie w realistyczny i rzeczowy sposób opisuje mechanizmy polityczne. W gruncie rzeczy to ideologia, której intelektualnym ojcem jest Thomas Hobbes. W swoich pracach, szczególnie w Lewiatanie, przedstawił wizję silnego państwa jako jedynego gwaranta bezpieczeństwa jednostki. Rozwiązując problem bellum omnium contra omnes,

\footnotetext{
14 Tamże, s. 31-32.

15 Tamże, s. 32-33.
} 
stworzył jednak nowy rodzaj zagrożenia: konflikt państw-molochów między sobą. Hobbes miał tego świadomość, niemniej uznał, że walka między nimi jest łatwiejsza do uniknięcia i powstrzymania, a także niesie za sobą mniejsze zagrożenia dla jednostek niż stan wojny każdego z każdym (nie cała bowiem populacja bierze w niej udział - co nie wydaje się tak oczywiste w epoce konfliktów totalnych). Joas uważa jednak, że wyjaśnienia te nie są ani klarowne, ani przekonujące. Wywodząca się z myśli Hobbesa Realpolitik jest zaś programowo pozbawiona aspektu moralnego i opiera się raczej na fałszywych interpretacjach rzeczywistości niż na trafnych jej rozpoznaniach. Ponadto, paradoksalnie podobnie jak naiwny pacyfizm, nie bierze pod uwagę całości skomplikowanych relacji łączących wojnę i wartości ${ }^{16}$.

Bardzo ważna wydaje mi się propozycja Joasa, by dogłębnie zbadać istniejące obecnie i w przeszłości mitologie przemocy. W nich właśnie niemiecki socjolog chce szukać źródeł niepowodzeń koncepcji długotrwałego pokoju. Myślenie o braku konfliktów możliwe jest tylko wtedy, jeśli wnikniemy w logikę „zewu przemocy” - nie ograniczając się jednak do jego opisu jako pewnego rodzaju nielogicznych wypaczeń. Celem powinno być przede wszystkim znalezienie w racjonalnym i moralnie uzasadnionym użyciu siły pewnych kryjących się pod nim pragnień i fantazji. Jako przykłady takich mitologii wymienia koncepcje: Maxa Schelera i Georga Simmla z czasów pierwszej wojny światowej, interpretujące wojnę jako wyzwolenie dla jednostki i nadzieję na inną nowoczesność, Georges’a Sorela rozumienie konfliktu jako drogi do uzyskania samoświadomości przez klasy niższe czy Frantza Fanona mit walki jako sposobu na odzyskanie podmiotowości i tożsamości przez skolonizowanych ${ }^{17}$.

W tym miejscu przyjrzyjmy się dokonanej przez Joasa analizie jednej z wyżej wymienionych mitologii przemocy - koncepcji wyzwalającej siły wojny, którą przedstawił Georg Simmel. Podobnie jak większość niemieckich badaczy i inteligencji z czasów pierwszej wojny światowej przyjął ją z gorącym, wydawałoby się frenetycznym wręcz, entuzjazmem. Uważał, podobnie jak Max Scheler, że konflikt ten będzie miał dla społeczeństwa i kultury rewitalizujący efekt. Myśl ta nie była jednak kontynuacją ani staroświeckiego militaryzmu, ani darwinizmu społecznego. Simmel widział w wojnie okazję do zerwania z tragicznymi tendencjami modernistycznej kultury. W czasach dominacji pieniądza bycie żołnierzem pozwala poczuć dosłowność codzienności. Ludzkie działania nie rozmywają się w morzu skomplikowanych i wyspecjalizowanych mechanizmów nowoczesności, ale krystalizują w pojedynczości walki, której rezultaty są natychmiastowe i ekstremalne. W ten też sposób człowiek potrafi wyczuwalnie dla siebie wypełnić czasowość. Podczas wojny jednostka zanurza się w ekstatycznej masie i na nowo poznaje wspólnotowość. Intensywność życia zostaje podniesiona do najwyższego poziomu. Co

16 Tamże, s. 33-34, na temat Hobbesa zob. także: H. Joas, W. Knöbl, dz. cyt., s. 18-21.

${ }^{17}$ H. Joas, War and Modernity, dz. cyt., s. 40-42. 
więcej, rewitalizacja kultury od razu przybiera masowy charakter, ponieważ to masy uczestniczą w walkach. Poszukiwanie „absolutnej sytuacji” zakończyło się więc według Simmla sukcesem. Wojna bowiem przynosi doświadczenia, które wymykają się racjonalnym uzasadnieniom, siłą oddziaływania podobne doświadczeniom seksualnym i głęboko religijnym. Tylko taki zaś rodzaj doświadczeń może wytworzyć wartości najbardziej fundamentalne, konstytutywne dla podmiotowości. Interpretacja dokonana przez Simmla jest brawurowa i bardzo optymistyczna. Ale też zanurzona w większej fali entuzjazmu ${ }^{18}$. Warto zaznaczyć, że we wszystkich nowoczesnych społeczeństwach pojawiła się podobna idea regenerującego efektu konfliktów, a nawet przemocy w ogóle (Fiodor Dostojewski, Pierre-Joseph Proudhon, Sorel) ${ }^{19}$. I rzeczywiście, pierwsza wojna światowa przyniosła olbrzymie zmiany, ale nie takie, jakich życzyli sobie ówcześni myśliciele. Wraz z ugrzęźnięciem walk w błocie okopów entuzjazm Simmla znacząco się zmniejszył ${ }^{20}$.

Mitologia przemocy, którą przedstawił Simmel, miała w sobie ukryty projekt społeczny. Zakładał on budowanie nowoczesności - której dotychczasowy kierunek wikłał jednostki w alienację, brak poczucia czasowości i sprawczości - na podstawie nowych wartości. Nie chodziło, co należy podkreślić, o zatrzymanie nieuniknionego procesu modernizacji. Koncepcja ta nie jest więc, mimo pozornych podobieństw, bliska hasłom faszystowskim, które w wojnie widziały odkrycie prawdziwej natury człowieka i fałszu liberalizmu. Simmel sięgał dużo głębiej, a zarazem nie proponował dyktatury jako właściwej formy rządów.

\section{Przemoc, trauma, powstawanie nowych wartości}

Dla Joasa duże znaczenie przy analizie wojny, pokoju i przemocy ma problem wartości. Z jednej strony zauważa, że dyskusja na ten temat zanikła po drugiej wojnie światowej ${ }^{21}$, a termin „wartości” wydaje się dzisiaj staroświecki, $\mathrm{z}$ drugiej strony przywołuje badania ${ }^{22}$, które pokazują, iż jednostki nie wiedzą, z jakiego powodu wyznają taki, a nie inny zbiór zasad. Przyczyny tego widzi $\mathrm{w}$ powojennej wierze w sukces modernizacji i socjalizmu, które mając jasno określoną linię ideologiczną oraz dominującą rolę w społeczeństwie, pytanie o pochodzenie wartości uznają za bezzasadne:

18 Tenże, Powstawanie wartości, dz. cyt., s. 117-120; tenże, War and Modernity, dz. cyt., s. 49; H. Joas, W. Knöbl, dz. cyt., s. 135-137.

19 H. Joas, War and Modernity, dz. cyt., s. 77.

20 Tenże, Powstawanie wartości, dz. cyt., s. 120.

21 Tamże, s. 26.

22 Tamże, s. 21. 
Jeżeli samą historię rozumie się jako w znacznym stopniu samonapędzający się proces modernizacji (jak w akademickich naukach społecznych) lub jako rządzący się własnymi prawami postęp w kierunku socjalizmu (jak u marksistów), to wartości są tak głęboko uwikłane w założonych tendencjach historycznych, że ich oderwanie od historii, relatywizacja w takiej czy innej perspektywie, kruchość realizacji są nie do pomyślenia ${ }^{23}$.

Opracowana przez Joasa koncepcja powstawania wartości, nierozerwalnie związana z problemem przemocy i wojny, wymaga głębszego rozpatrzenia.

Badacz uważa, że wartości wyrastają z dwóch procesów: samoformowania i samotranscendencji. Szczególnego wytłumaczenia wymaga termin „samotranscendencja”, który nie ma nic wspólnego z religijnie rozumianym pojęciem „transcendencja” i polega na przekraczaniu przez osobę symbolicznych granic swojego „ja”, ustalonego stosunku do świata i innych jednostek. Dokonuje się ono najczęściej za sprawą miłości czy doświadczeń religijnych (jednak to siła tego przeżycia, a nie jego religijny charakter, ma decydujące znaczenie). Joas nazywa tę drogę entuzjastyczną - jednostka bowiem otwiera się na nowość i inność z własnej woli ${ }^{24}$.

Niemiecki socjolog zauważa jednak, że w procesie samotranscendencji równie ważne, a nawet powodujące dużo głębsze i bardziej radykalne zmiany, jak doświadczenia, do których podchodzimy z entuzjazmem, są doświadczenia negatywne, związane ze śmiercią, zagrożeniem, wykorzenieniem ze świata i dotychczasowych granic. Przemoc jest wymuszonym otwarciem granic jednostki, którą pozostawia niezreintergrowaną, bez punktu zaczepienia w pozytywnych wartościach. Gwałt traumatyzuje w szczególny sposób, ponieważ wymusza mechanizm, który jest formą miłosnego otwarcia na drugiego człowieka.

W namyśle nad sposobem przepracowania przemocy na nowe wartości Joas sięga i po historię myśli politycznej XX wieku, i, co interesujące, po literaturę. $Z$ jednej strony ze szczególną wnikliwością przygląda się powstawaniu w czasie po drugiej wojnie światowej uniwersalistycznych praw człowieka. $\mathrm{Z}$ drugiej, dokonuje interpretacji książki Alfreda Döblina Hamlet, czyli kres dtugiej nocy, której główny bohater doświadcza traumy podczas walk. Analizy te pozwoliły Joasowi na dostrzeżenie mechanizmu odbudowywania wartości, dość podobnego i w wypadku zbiorowości, i jednostki. Proces ten składa się z sześciu następujących po sobie etapów ${ }^{25}$.

${ }^{23}$ Tamże, s. 26.

${ }^{24}$ Cały opis mechanizmu powstawania wartości: H. Joas, The Sacredness of the Person: A New Genealogy of Human Rights, tłum. A. Skinner, Georgetown 2013, s. 69-70 oraz tenże, War and Modernity, dz. cyt., s. 20.

${ }_{25}$ Opis tych faz na podstawie pracy H. Joas, Dtuga noc żatoby. Narracja jako wyjście z przemocy?, tłum. Ł. Tischner, „Konteksty Kultury” 2017, z. 2 oraz tenże, The Sacredness of the Person..., dz. cyt., s. 77-79. 
Faza pierwsza to wtargnięcie przemocy w „świętą przestrzeń ciała”, złamanie symbolicznych granic jednostki. Doświadczenie to niszczy poczucie zakorzenienia w świecie, możliwość przewidywania, poczucie czasowości. Rodzi traumę, która łączy się z kolejnym stadium - stratą łączności człowieka ze światem przez niemożliwość wyartykułowania rzeczywistości i brak odpowiedniego języka. Dwa pierwsze etapy dotyczą więc samego mechanizmu wtargnięcia przemocy w ,ja” człowieka.

Faza trzecia rozpoczyna powolny proces wychodzenia z traumy i odnajdywania nowych wartości. Według Joasa najważniejsze dla straumatyzowanej jednostki jest odnalezienie możliwości wypowiedzenia się i wyjścia poza rozbite „ja”. Możliwość taką widzi w mocy narracji. Etap trzeci dotyczy właśnie tego procesu - jednostka przez czynność opowiadania lub wczuwania się w czyjeś historie poznaje inne tożsamości. Czynności te stają się formą poszukiwania nowej prawdy o sobie. Objawia się ona w etapie czwartym - człowiek dzięki opowieściom, szczególnie zaś dotyczącym przemocy, konstytuuje nowe wartości i nowe formy relacji ze światem. Pełne wyjście z traumy i skonstruowanie ,ja” nie jest jednak skończone. Doświadczenia negatywne odcisnęły bowiem piętno także na relacjach społecznych jednostki. „Ja" zostało okaleczone w obrębie pewnej zbiorowości - jej zasad i struktur. Powstające wartości będą się więc w krytyczny sposób do niej odnosić. Stąd też krok piąty - rozważenie druzgocących dla dawnych relacji społecznych konsekwencji przyjęcia nowych zasad. Etap zaś szósty i ostatni to poszerzenie politycznego, społecznego i moralnego znaczenia nowych wartości o wymiar egzystencjalny oraz religijny. W tym momencie według Joasa jednostka dociera do ostatecznej rekonstrukcji ,ja” na nowych warunkach, wychodzi z traumy (choć pamięć o niej oczywiście pozostaje, zresztą w samym rdzeniu samoidentyfikacji) oraz umiejscawia się w innym kontekście w stosunku do zbiorowości.

Drogę powstawania ogólnych, uniwersalnych wartości na gruncie historii wojen i przemocy Joas analizuje w swojej książce The Sacredness of the Person: A New Genealogy of Human Rights. Tym, co w szczególny sposób zwraca jego uwagę, jest historia powstania praw człowieka. Jak sam przyznaje, nie interesują go dzieje przemian kar, tortur, systemu sądowego, a raczej fundamentalny proces „sakralizacji osoby”, który dokonał się w drugiej połowie XVIII wieku ${ }^{26}$. Badacz ukazuje także, jak proces ten zaburzany był przez sakralizację rasy, narodu czy klasy społecznej, takie jak francuski protofaszyzm Charles’a Maurrasa czy dojrzałe formy ideologii faszystowskiej we Włoszech i Niemczech ${ }^{27}$.

${ }^{26}$ Por. „(...) the reforms of penal law and penal practice, and the rise of human rights in the late eighteenth century, are the expression of a profound cultural shift in which the human person became a sacred object". Tenże, The Sacredness of the Person..., dz. cyt., s. 49-51; cyt. tamże, s. 49.

27 Tamże, s. 60. 
Joas zauważa, że we wszystkich głównych tekstach dotyczących praw człowieka pojawia się problem historii przemocy i szkód, które wyrządził XX wiek. Już pisane zaraz po drugiej wojnie światowej konstytucje niemieckich landów jasno odnoszą się do doświadczeń niedawnego konfliktu i nazizmu. Dokumenty te posługują się określeniami „anihilacja”, „barbarzyństwo”, wiele jednak tekstów z tych czasów odnosiło się do wojny również w mniej oczywisty sposób, choćby przez przywoływanie koncepcji prawa naturalnego jako przeciwnemu nihilistycznemu relatywizmowi ${ }^{28}$. Według Joasa doświadczenia zbrodni nazistowskich wpłynęly też na tekst Powszechnej deklaracji praw cztowieka. Wpis o prawie do życia jest reakcją na hitlerowską politykę eutanazji, prawo do ludzkiego traktowania przeciwstawione zostało obozom koncentracyjnym. Dokument w jasny sposób wynikał więc z doświadczeń wojennych i wprowadzał do społeczeństwa normy, które miałyby zapobiegać konfliktom, a w najgorszym wypadku - czynić je mniej bezwzględnymi i traumatyzującymi. Był zarazem nowym językiem opowieści o szoku, jakiego doświadczyły społeczeństwa zachodnie ${ }^{29}$. Joas zauważa jednak, że Deklaracja... nie w pełni korzystała z negatywnych doświadczeń stalinizmu (zbrodnie tego totalitaryzmu nie były wtedy jeszcze na Zachodzie tak dobrze znane), pomijała też sprawę kolonializmu. Dokument nie oddawał więc całej rozległości doświadczeń przemocy tamtych czasów ${ }^{30}$.

\section{Zakończenie}

W przedstawionych tutaj rozważaniach starałem się ukazać najważniejsze i najbardziej oryginalne z koncepcji Hansa Joasa dotyczących wojny, pokoju i przemocy. Joas w klarowny sposób krytykuje braki i niedoskonałości neoliberalnej nowoczesności, nie jest jednak jej przeciwnikiem. Poszukuje raczej nowej, bardziej skutecznej drogi do powstrzymania konfliktów i katastrof, którymi naznaczony był wiek XX. Usiłuje odnaleźć prawdziwe fundamenty przemocy nie tylko w wydarzeniach historycznych, ale także w jej mitologiach, zbyt łatwo ignorowanych przez dominujące narracje, zbyt pochopnie uznawanych za nieracjonalne czy archaiczne. Zarazem też zwraca uwagę na konieczność niesienia pomocy poszkodowanym, straumatyzowanym, wewnętrznie zdezintegrowanym przez wojnę. Wydaje się więc, że koncepcje niemieckiego badacza mogą znaleźć szerokie zastosowanie w socjologicznych i politologicznych analizach istniejących oraz przyszłych konfliktów. Warto również zastanowić nad ukazaną przez Joasa na przykładzie powieści Döblina możliwością użycia literatury jako narzędzia pomocnego $\mathrm{w}$ badaniach dotyczących mechanizmów

${ }_{28}$ Tamże, s. 71-72.
${ }_{29}$ Tamże, s. 72-73.
${ }_{30}$ Tamże, s. 74-75. 
powstawania wartości, a szczególnie wychodzenia jednostki z traumy dzięki opowieści. Są one tym bardziej wartościowe, że wbrew optymistycznym wizjom przyszłości uwolnionej od przemocy wiek XXI zaczął się od ataku terrorystycznego na bezbronnych cywili.

\section{Bibliografia}

Joas H., Dtuga noc żatoby. Narracja jako wyjście z przemocy?, thum. Ł. Tischner, „Konteksty Kultury” 2017, z. 2.

Joas H., Powstawanie wartości, tłum. M. Kaczmarczyk, Warszawa 2009.

Joas H., The Sacredness of the Person: A New Genealogy of Human Rights, thum. A. Skinner, Georgetown 2013.

Joas H., War and Modernity, tłum. R. Livingstone, Malden 2003.

Joas H., Knöbl W., War in Social Thought, tłum. A. Skinner, Princeton 2013.

Malešević S., The Sociology of War and Violence, Cambridge 2010.

Shaw M., War and Genocide: Organised Killing in Modern Society, Cambridge 2003.

The Axial Age and Its Consequences, red. R.N. Bellah, H. Joas, Cambridge-London 2012. 